\title{
Runoff generation processes during the wet-up phase in a semi-arid basin in Iran
}

\section{H. Zarei ${ }^{1}$, A. M. Akhondali ${ }^{1}$, H. Mohammadzadeh ${ }^{2,3}$, F. Radmanesh ${ }^{1}$, and H. Laudon ${ }^{4}$}

${ }^{1}$ Department of Hydrology and Water Resources, Shahid Chamran University of Ahvaz, Ahvaz, Iran

${ }^{2}$ Department of Geology, Ferdowsi University of Mashhad, Mashhad, Iran

${ }^{3}$ Groundwater Research Center, Ferdowsi University of Mashhad, Mashhad, Iran

${ }^{4}$ Department of Forest Ecology and Management, SLU - Swedish University of Agricultural Sciences, 90183 Umeå, Sweden

Received: 11 October 2013 - Accepted: 21 November 2013 - Published: 2 April 2014

Correspondence to: H. Zarei (zareih@scu.ac.ir)

Published by Copernicus Publications on behalf of the European Geosciences Union.

Runoff generation processes during the wet-up phase in asemi-arid basin

H. Zarei et al.

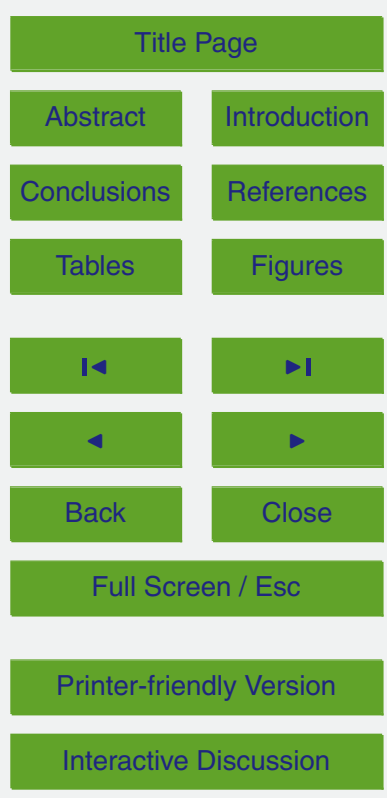




\section{Abstract}

Understanding the hydrological processes in catchments is important for water resources management, particularly in semi-arid regions of the world. To contribute to this field, dominant runoff generation processes in a semi-arid basin $\left(283 \mathrm{~km}^{2}\right)$ in 5 Southwestern Iran were investigated using analysis of hydrometric data in combination with natural isotopic tracers through the wet-up phase of a rainy season. The analysis of seven rainfall-runoff events during the rainfall dominated period illustrated the role of antecedent base flow and cumulative rainfall for explaining the hydrological response. Three distinct storm events and the corresponding discharge were collected and ana10 lyzed for oxygen-18 and deuterium isotope composition. The results show that during the wetting-up cycle, the runoff ratio during storm events increased progressively from 1 to $10 \%$. Higher event runoff ratios following catchment wet-up were shown to be directly linked to changes in soil moisture, which in turn controlled the runoff generation processes. In line with the hydrometric results, the two-component hydrograph separation using $\delta^{18} \mathrm{O}$ and $\delta^{2} \mathrm{H}$ demonstrated a clear connection to the antecedent wetness conditions. The results suggest that the runoff ratios during storms and the partitioning of event and pre-event water fractions are sensitive to the amount of catchment wet-up and could hence be strongly impacted by changes in the timing, duration and amount of precipitation in the future.

\section{Introduction}

Improving the understanding of hydrological processes in catchments is important for water management and the availability of surface water and groundwater resources, both in terms of quality and quantity (Hrachowitz et al., 2011). This is especially true in arid to semi-arid regions of the world where the lack of water often is a major limitation for the livelihood of humans. Gaining better insight into the hydrological functioning in these regions is therefore urgently needed especially in the light of climate change

\section{HESSD}

$11,3787-3810,2014$

Runoff generation processes during the wet-up phase in asemi-arid basin

H. Zarei et al.

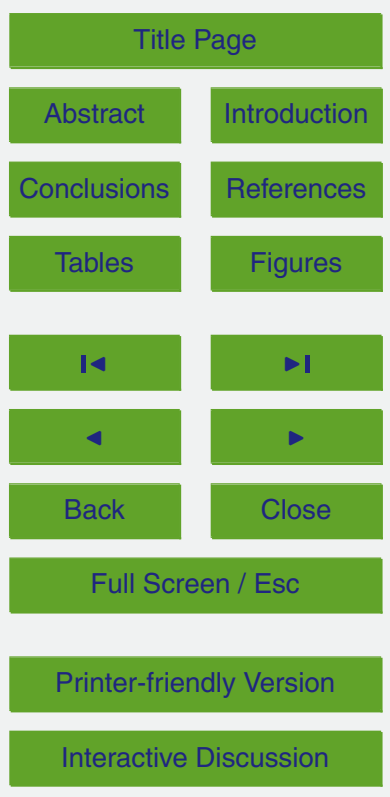


that risks to further restrict the water availability in the future (Abbaspour et al., 2009; Hemadi et al., 2011; Zohrabi et al., 2011; Roshan and Grab, 2012). Hydrometric data and environmental isotopes are important tools that can be used to quantify the contributions of runoff components during different hydrological conditions and provide 5 direct insights into the dominating hydrological processes (Didszun and Uhlenbrook, 2008; Lyon et al., 2008; Munyaneza et al., 2012).

The use of isotopic hydrograph separation (IHS) is one of the most powerful methodologies to understand hydrological processes. IHS is commonly used to determine the fractions of event (new) water and pre-event (old) water contributions to streamflow 10 during hydrological episodes (Hooper and Shoemaker, 1986; Laudon and Slaymaker, 1997; Richey et al., 1998; Chen et al., 2008). Most previous work using IHS has been carried out in small basins in humid/boreal region (e.g. Uhlenbrook et al., 2002; Laudon et al., 2007; Blume et al., 2008; Wenninger et al., 2008). The general finding from most of these studies have been that the contributions from pre-event water during 15 rain storms and snowmelt events are dominating. The dominance of pre-event water means that most water during the rain (or snowmelt) event comes from water already in the catchment prior to the precipitation event started, and hence only a small fraction of the stream water originates from the recent rainfall (or snowmelt). This finding has important implications for our understanding on how water is routed through the catchment and can provide valuable knowledge that can help maintain both the quality and quantity of our water resources.

Less research has been conducted in more water limited regions of the world using IHS (Mul et al., 2008; Bohté et al., 2010). This is especially true for the large parts of the Middle East which generally is characterized by an arid to semiarid climate with a strong seasonality in precipitation, including relatively wet winters and dry summers (Alijani and Harman, 1985; Ballato et al., 2010). This region is sensitive to climate change as an alteration in the water balance could affect the existence of millions of people. In populated regions with semi-arid climate, understanding hydrological
HESSD

$11,3787-3810,2014$

Runoff generation

processes during the wet-up phase in asemi-arid basin

H. Zarei et al.

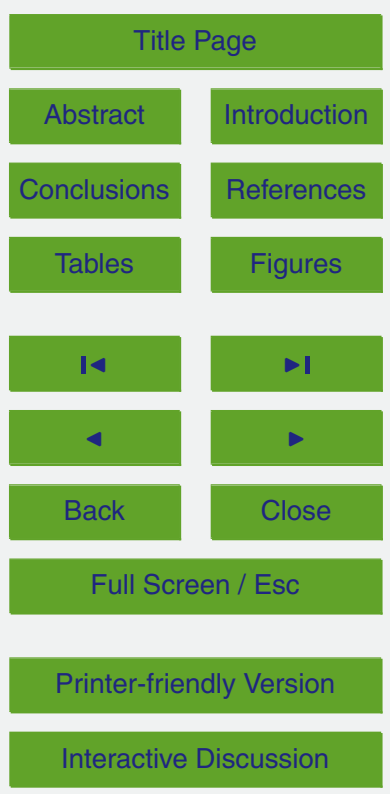


processes are even more essential since droughts can result in drinking water deficiency and severe crop loss.

In order to better understand the hydrological functioning of a semi-arid region we studied the hydrological response over one rain-season in the mountainous meso-scale

5 Abolabas basin in Iran. The objective of this work was to improve the basic understanding of (1) the hydrological response to rain episodes as the catchment is wetting up after almost six months of drought, and (2) the contribution of event/pre-event water change over this transition period. To answer these questions, seven events and corresponding discharge during one hydrologic year were monitored, of which three 10 episodes were sampled for oxygen-18 and deuterium isotopes to quantify old and new water contributions to the total runoff.

\section{Material and methods}

\subsection{Site description}

This study was carried out in the meso-scale Abolabas karst basin, with an approx15 imate catchment area of $283 \mathrm{~km}^{2}$, located in the Zagros Mountains in southwestern Iran (Fig. 1). The population of the city of Baghmalek and its vicinity that depend on the water from the catchment is approximately 65000 . Several small villages exist within the study catchment, generally living from subsistence agriculture. The basin is also of more general interest as it is an important headwater source for downstream cities and has therefore become one of the most investigated catchments in the country for hydrological research due to its importance as a drink water resource in the region and nationally (Saghafian and Ghermez Cheshmeh, 2008; Rezaei Sadr et al., 2012). Karst formations cover about $64 \%$ of the total surface area of the basin. Elevation ranges from 691 to 3283 ma.s.l., with an average elevation of $1885 \mathrm{~m}$; where the higher regions are characterized by steep slopes, often with shallow soil coverage and the lower parts mainly consist of deep alluvial deposits.

\section{HESSD}

$11,3787-3810,2014$

Runoff generation processes during the wet-up phase in asemi-arid basin

H. Zarei et al.

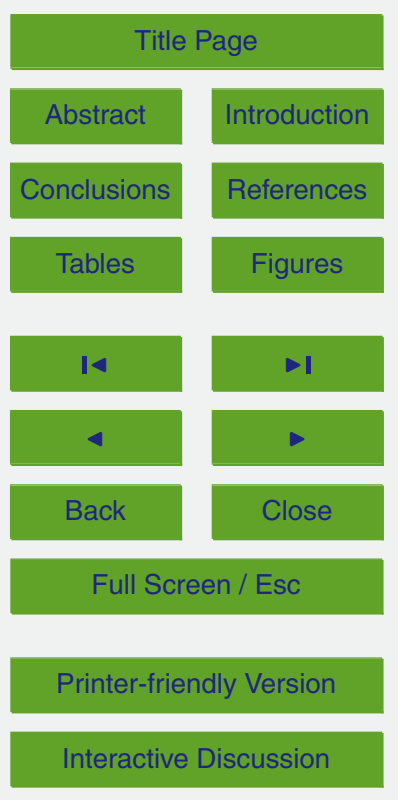


The long term mean annual precipitation and temperature is $825 \mathrm{~mm}$ and $21^{\circ} \mathrm{C}$, respectively. The annual average potential evapotranspiration at Baghmalek station is estimated to be $1457 \mathrm{~mm}$. The majority of precipitation falls in the rainy season (November till April) in the form of rain and partly as snow at higher elevations. Runoff is dom5 inated by rainfall between November and February, after that, snow melt from higher elevations become dominating.

\subsection{Sampling and field measurements}

The rainfall and discharge data were obtained from the hydrological database of Khuzestan Water and Power Authority, Ahvaz. There are two long-term monitored rain gauges in the catchment, Baghmalek station at lower elevation (720 m a.s.l.) is a continuously recording rain gauge and Malagha at an intermediate elevation (1080 m a.s.I.) is monitored manually on a daily basis (Fig. 1). Runoff was monitored at the Pole Manjeniq hydrological station continuously (Fig. 1) using an established relationship between the stage and discharge.

15 Three distinct storm events and the corresponding discharge response were sampled for stable isotope composition of oxygen-18 $\left(\delta^{18} \mathrm{O}\right)$ and deuterium $\left(\delta^{2} \mathrm{H}\right)$ during the rainy season of December 2010 to February 2011. For each event spatially distributed temporary rain gauges were used to collect rain water in the basin. Precipitation was collected at six sites for each event (Fig. 1) using simple devices consisting 20 of a collection area of $0.04 \mathrm{~m}^{2}$. The funnel shaped collection device was connected to the sample bottle by a U-shaped trap designed to remain filled with water after the precipitation event, thus protecting the water sample from evaporation and associated isotopic fractionation. Water samples from the main channel of Abolabas River at Pole Manjeniq station were collected manually every $30 \mathrm{~min}$ during the three events. The water samples were collected into $60 \mathrm{~mL}$ polyethylene wide-mouth round bottles. Prior to sampling, new bottles were treated with $10 \% \mathrm{HCl}$, washed with deionized water at least three times, and rewashed three times in-situ using stream water. Water samples were hand-dipped along the shore at a water depth of $10-15 \mathrm{~cm}$ at a turbulent section

\section{HESSD}

$11,3787-3810,2014$

Runoff generation processes during the wet-up phase in asemi-arid basin

H. Zarei et al.

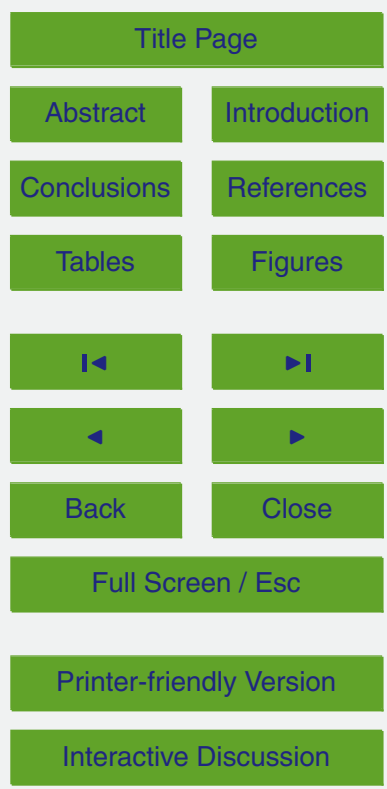


of the river. Sample bottles were filled to the brim without trapping any air bubbles and kept refrigerated at the water quality laboratory of Ahvaz University. Finally based on the discharge fluctuations, a total of 60 samples (42 stream, and 18 rain) were analyzed for isotopic content.

\section{$5 \quad 2.3$ Laboratory analysis}

The analyses were performed on an Isotope Ratio Mass Spectrometer (IRMS) Delta Plus XP (Thermo, Germany) interfaced with a Gas Bench II in G.G. Hatch stable isotope laboratory at University of Ottawa, Canada.

Oxygen-18 Analysis: samples and internal standards were flushed with a gas mixture of $2 \% \mathrm{CO}_{2}$ in helium off-line. The closed exetainers were left to equilibrate at room temperature for a minimum of $18 \mathrm{~h}$.

Deuterium Analysis: to the samples and internal standards Hokko beads were added to the exetainer vials before being flushed with a gas mixture of $2 \% \mathrm{H}_{2}$ in helium offline. The exetainers were left to equilibrate at $25.0 \mathrm{C}$ for $1.5 \mathrm{~h}$ minimum (De Groot, 15 2008).

All data is reported in Delta notation $\delta$, the units are per mil (\%o) and defined as

$\delta=\frac{R_{x}-R_{\mathrm{std}}}{R_{\mathrm{std}}} \times 1000$

where $R$ is the ratio of the abundance of the heavy to the light isotope, $x$ denotes sample and std is an abbreviation for standard. The measurement precision for $\delta^{18} \mathrm{O}$ and $\delta^{2} \mathrm{H}$ were \pm 0.15 and $\pm 2 \%$, respectively. All $\delta^{18} \mathrm{O}$ and $\delta^{2} \mathrm{H}$ values are reported as per mill (\%) and normalized to internal standards calibrated to International standards VSMOW.

\section{HESSD}

$11,3787-3810,2014$

Runoff generation processes during the wet-up phase in asemi-arid basin

H. Zarei et al.

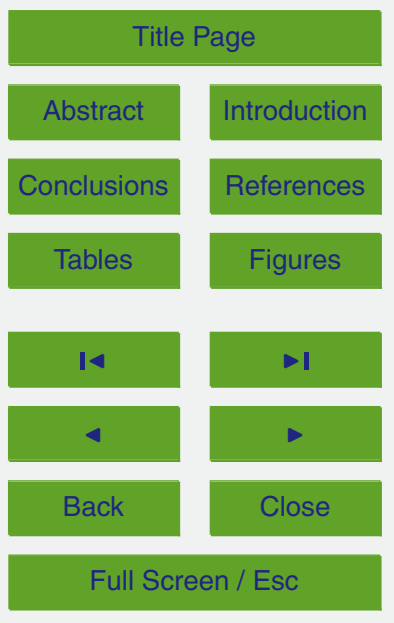

Printer-friendly Version

Interactive Discussion 


\subsection{Isotopic Hydrograph Separation (IHS) technique}

For a conservative tracer, a simple mixing equation for a two-component hydrograph separation model is described as follows (see Buttle, 1994 for a review):

${ }_{5} Q_{\mathrm{t}} C_{\mathrm{t}}=Q_{\mathrm{p}} C_{\mathrm{p}}+Q_{\mathrm{e}} C_{\mathrm{e}}$

where $C$ is the concentration of each solution, $Q$ is the flow, and the subscripts $\mathrm{t}, \mathrm{p}$, and e refer to pre-event water (old previously stored water as soil and groundwater), event water (new recently derived precipitation water), and total flow, respectively, together with a mass constrain.

${ }_{10} Q_{\mathrm{t}}=Q_{\mathrm{p}}+Q_{\mathrm{e}}$

Following Eqs. (2) and (3), the proportion of flow that arises from pre-event may be written as

$Q_{\mathrm{p}}=\left(\frac{C_{\mathrm{t}}-C_{\mathrm{e}}}{C_{\mathrm{p}}-C_{\mathrm{e}}}\right) Q_{\mathrm{t}}$

This two-component mixing model was first used by Pinder and Jones (1969) for a variety of chemical tracers to quantify groundwater and direct runoff contributions to total runoff and has since been widely used. The details and assumptions of the hydrograph separation method are discussed in several previous studies (Sklash and Farvolden, 20 1979; Wels et al., 1991; Buttle, 1994). The basic assumption is that the isotopic composition of baseflow at the sampling point is represenative for the pre-event water in the catchment and that composition of collected precipitation describes the event water (Buttle, 1994; Mul et al., 2008).

Due to spatial variation, hydrograph separation was in this paper performed us25 ing weighted mean values for each event, based on all collected rainfall samples (Mcdonnell et al., 1990):
HESSD

11, 3787-3810, 2014

Runoff generation processes during the wet-up phase in asemi-arid basin

H. Zarei et al.

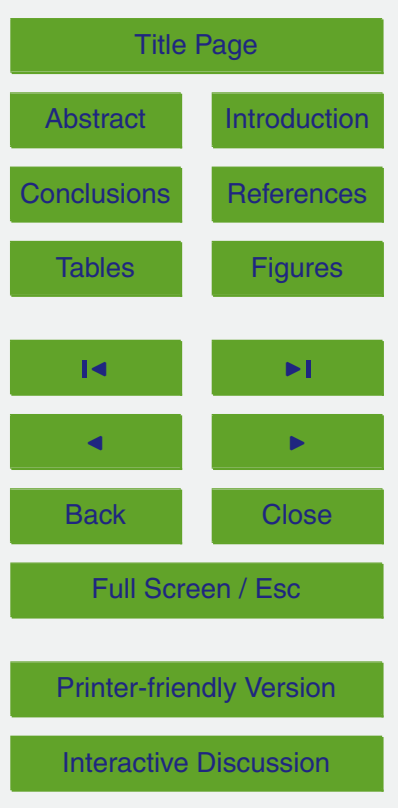

Interactive Discussion 
$\delta^{18} O=\frac{\sum_{i=1}^{n} P_{i} \delta_{i}}{\sum_{i=1}^{n} P_{i}}$

where $P_{i}$ and $\delta_{i}$ denote fractionally collected rainfall depth and isotope content, respectively.

\section{$5 \quad 3$ Results}

\subsection{Rainfall-runoff observations}

Following a period of six months of drought conditions resulting in the annual low flow, the rainy season began in the beginning of December with several consecutive storm events (Fig. 2). The discharges at the outlet of the Abolabas catchment measured at the Pole Manjeniq gauging station, for data recorded from November 2010 till May 2011, ranged from low flow $0.04 \mathrm{mmd}^{-1}$ to maximum flow of $5.7 \mathrm{mmd}^{-1}$. Total rainfall during the study period, from November 2010 to April 2011, was $393 \mathrm{~mm}$ which generated total a runoff of $107 \mathrm{~mm}$, of which $27 \%$ came during high flow events.

During the 2010/11 rainy season a total of eleven events were recorded of which seven events occurred during the rainfall dominated period, while the remaining four events occurred during the snowmelt period. Due to the lack of sufficient information about the isotopic composition of snowmelt, only the rainfall dominated period is discussed further. The characteristics of the rainfall-runoff events are presented in Table 1 . The range of the runoff ratio $(P / R)$ for the basin for seven storms ranged from below 1 to $10 \%$. The runoff ratio was at the start of the rainy season (below $1 \%$ ) but steadily increased (to approximately $10 \%$ ) as the wet season progressed.

To improve the understanding of hydrological processes in the catchment, strength of regression between runoff ratio and characteristics of the rainfall-runoff events are discussed and presented in Table 2 . The results reveal a significant $(P<0.001)$ exponential relationship between runoff ratio and base flow of the events (Fig. 3a) with

Runoff generation processes during the wet-up phase in asemi-arid basin

H. Zarei et al.

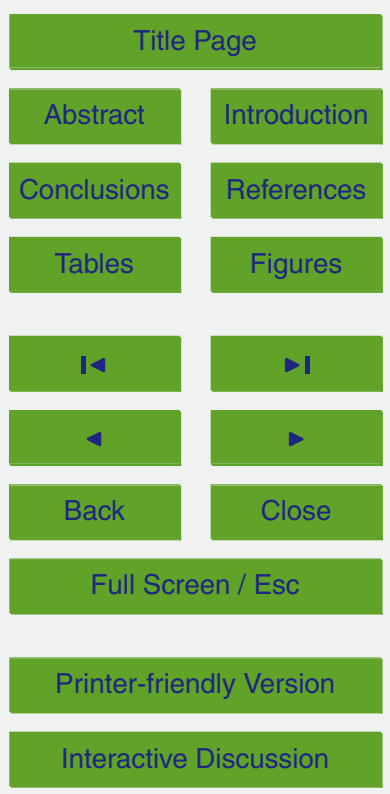


a correlation coefficient $(r)$ of 0.97 . Also a strong exponential relationship between runoff ratio and cumulative rainfall was observed ( $r=0.99)$ (Fig. 3b). Using exponential regression as an exploratory tool, antecedent base flow and cumulative rainfall was the two factors that best explained the runoff ratio.

\section{$5 \quad 3.2$ Results of isotopes tracer studies}

Three runoff events during the rainy period where investigated closer by using $\delta^{18} \mathrm{O}$ and $\delta^{2} \mathrm{H}$ isotopic tracers. Statistical parameters of isotopic contents observed in Abolabas catchment during the investigated events are shown in Table 3. Because of the relatively large basin size and topographic release, variation in the isotopic content of the precipitation was large (Table 3 ).

The first rainfall event (event 1 ) equaled $12.0 \mathrm{~mm}$ and occurred during dry conditions, as it was the first precipitation event for close to six months. The observed peak flow at the outlet of the basin (Pole Manjeniq station) was $0.7 \mathrm{~mm} \mathrm{~d}^{-1}$. The calculated mean $\delta^{18} \mathrm{O}$ and $\delta^{2} \mathrm{H}$ content of the rainfall were $-1.95 \%$ o with standard deviation (SD) of $15(0.76 \%$ ) and $-7.74 \%$ (SD $4.33 \%$ ), respectively (Table 3$)$, whereas the initial $\delta^{18} \mathrm{O}$ and $\delta^{2} \mathrm{H}$ amount in stream water (pre-event water) was -4.77 and $-21.19 \%$, respectively (Fig. 4a). Despite the large variation between the precipitation and stream base flow, the isotopic composition response of the river water during the event was negligible (Fig. 4a and b).

20 The second event (event 2) occurred during wetter conditions following five days of antecedent rainfall (about $31 \mathrm{~mm}$ ). The peak flow during this event caused by the $25.2 \mathrm{~mm}$ rainfall was $2.3 \mathrm{mmd}^{-1}$ at the outlet of the Abolabas basin. The calculated mean $\delta^{18} \mathrm{O}$ and $\delta^{2} \mathrm{H}$ content of the rainfall was $-1.50 \%$ (SD $0.71 \%$ ) and $7.34 \%$ (SD $4.14 \%$ ), respectively, which was significantly different from the initial $\delta^{18} \mathrm{O}$ and $\delta^{2} \mathrm{H}$ of 25 the stream water (pre-event water) of -4.85 and $-24.00 \%$, respectively. Interestingly, in this case, the isotopic content is higher than the other two events (Fig. 4c and d).

Similar to event 2 , event 4 occurred during relatively wet conditions (five day antecedent rainfall was $35 \mathrm{~mm}$ ). The peak flow of the event at the basin outlet following 3795
HESSD

$11,3787-3810,2014$

Runoff generation processes during the wet-up phase in asemi-arid basin

H. Zarei et al.

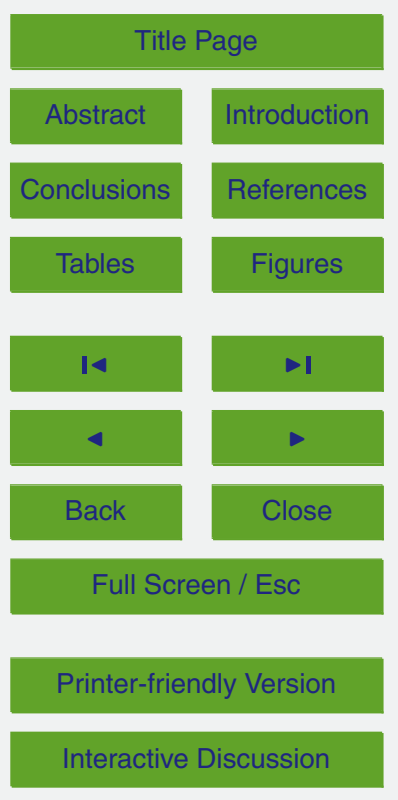


the $21.0 \mathrm{~mm}$ of rain was $3.6 \mathrm{mmd}^{-1}$. The rainfall had a mean $\delta^{18} \mathrm{O}$ and $\delta^{2} \mathrm{H}$ content of $-3.73 \%$ (SD $0.43 \%$ ) and $-17.55 \%$ (SD $3.36 \%$ ), respectively (Table 3 ). The initial $\delta^{18} \mathrm{O}$ and $\delta^{2} \mathrm{H}$ amount in stream water (pre-event water) was -4.83 and $-25.20 \%$, respectively. The episodic stream response was large small compared to event 1 but 5 small compared to event 2 (Fig. $4 \mathrm{e}$ and f).

\subsection{Results of isotopic hydrograph separation}

A significant difference in the isotopic composition is necessary to perform a twocomponent hydrograph separation. This method limitation was fulfilled for the three events, with the lightest isotopic content (for both $\delta^{18} \mathrm{O}$ and $\delta^{2} \mathrm{H}$ ) observed in the preevent water, and the heaviest during rainfall.

Using the isotopic content of baseflow (pre-event), rainfall (event) and river water, the pre-event water fraction was calculated (Eq. 4). Results from the two-component hydrograph separations for the events 1,2 and 4 are presented in Fig. 5. The twocomponent hydrograph separation model using $\delta^{18} \mathrm{O}$ and $\delta^{2} \mathrm{H}$ led to a dominance 15 of pre-event water contribution for the investigated events at Pole Manjeniq station. Percentages of pre-event fraction, separated using $\delta^{18} \mathrm{O}$ for the peak flows and total event were 94 and $96 \%$ (event 1), 56 and $72 \%$ (event 2) and 53 and $92 \%$ (event 4), respectively. Percentages of pre-event water, separated by $\delta^{2} \mathrm{H}$ at the peak flows and total event were similar with 100 and $99 \%$ (event 1), 57 and $72 \%$ (event 2) as well as 33 and $88 \%$ (event 4), respectively.

\section{Discussion}

Improving the understanding of hydrological response in catchments is essential for water resources management. Numerous isotopic studies have focused on evaluating hydrological response in karst landscapes in humid regions around the world (e.g. Katz et al., 1997; Jones et al., 2000; Aquilina et al., 2006), often with the intention to improve

\section{HESSD}

11, 3787-3810, 2014

Runoff generation processes during the wet-up phase in asemi-arid basin

H. Zarei et al.

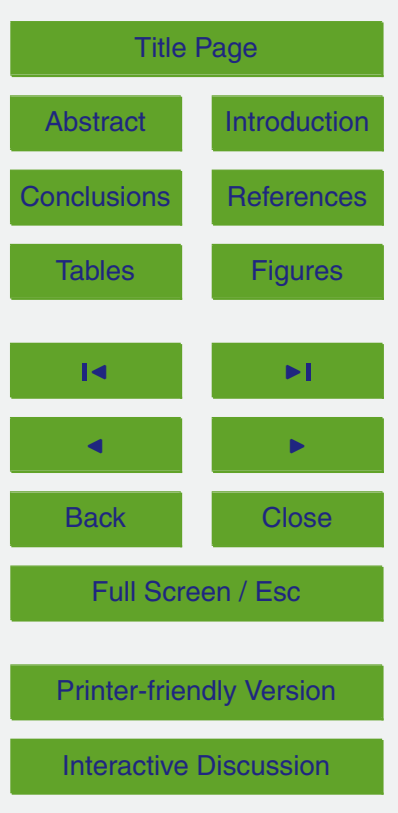


the understanding of hydrological responses during episodes. However, few hydrograph separation studies have been conducted in semi-arid regions. Here we focus on a meso-scale karst basin during a wet-up period that began after six months of drought conditions. In order to improve the basic understanding of the hydrological response to 5 rain episodes and to calculate the partitioning between event/pre-event water, a number of hydrological events during one hydrologic year were monitored and sampled for stable isotope composition of oxygen-18 $\left(\delta^{18} \mathrm{O}\right)$ and deuterium $\left(\delta^{2} \mathrm{H}\right)$.

The rainfall-runoff transformation is a complex and non-linear process. However the most important cause of non-linearity is likely represented by the effect of antecedent 10 conditions (Rallison and Miller, 1981; Singh, 1988). The observed low runoff ratios (from $<1 \%$ to $\sim 10 \%$ ) indicate that only a small fraction of the rainfall was directly translated to stream flow during individual events, especially during the first phase of the wet season. Two reasons can contribute to this pattern. The first is that precipitation at elevations above 2500 m.a.s.I arrives, and accumulate, as snow and hence approximately $30 \%$ of the catchment does not contribute to stream water during the period considered. This area is largest/smallest during January/April, respectively. However, even if the snow accumulation part of the catchment is significant, it is not large enough to explain the observed pattern.

The second factor is that following the six months of drought conditions most of the early precipitation results in a recharge of the catchment soil and result in that only a small fraction of the riparian areas closest to the river will contribute to stream flow. As the soils in the study catchment overlying the bedrock are porous with relatively high infiltration rates, most of the precipitation will infiltrate the soils resulting in little overland flow. As the catchment wets-up higher runoff ratios results, indicating an increased hillslope contribution. According to water level fluctuations of piezometer wells in the basin ground water level can increase by up to $16 \mathrm{~m}$, during the rainy season (Anonymous, 2007). This suggests a large soil recharge potential and that the storm flow reaches the stream largely through the soil by subsurface runoff mechanisms. New rainwater is able to recharge the aquifer, possibly through fractures, and mobilizes older water that has

\section{HESSD}

$11,3787-3810,2014$

Runoff generation processes during the wet-up phase in asemi-arid basin

H. Zarei et al.

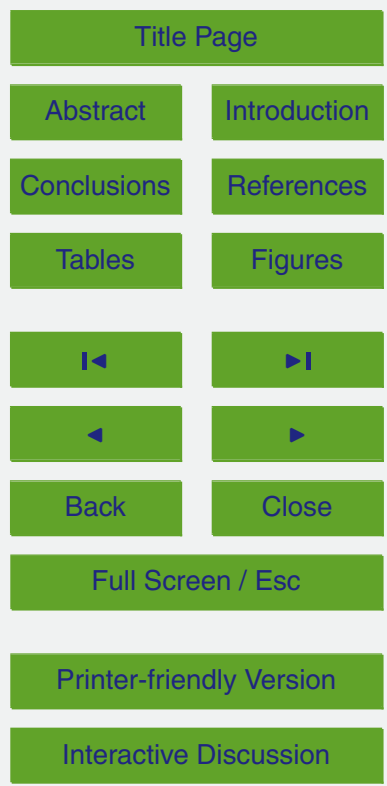


been residing in smaller fractures and pores within the catchment soil and bedrock. This runoff generation mechanisms was supported by observed isotopic contents in stream water which are closer to the content of pre-event water for the three events (Table 2). The result is also in line with the results from other studies (Wenninger et al., 5 2008; Hrachowitz et al., 2011; Munyaneza et al., 2012) who found that event runoff ratios were low for most catchments with comparable semi-arid conditions.

In line with the hydrometric results, the two-component hydrograph separation using $\delta^{18} \mathrm{O}$ and $\delta^{2} \mathrm{H}$ demonstrated a clear connection to the antecedent wetness conditions During event 1 , which occurred during the driest conditions, the runoff consisted of 10 close to $100 \%$ pre-event water. As the catchment wetted up after some progressive rain storms, the portion of event water during events 2 and 4 became larger. Consistent with the increase in antecedent moisture, the amount of event water contribution increased during peak flow, suggesting a more direct link between rainfall and runoff. Still however, it can be concluded from the rainfall-runoff response analysis and the isotopic content of the stream water that the runoff generation was dominated by subsurface flows (Fig. 5). Similar findings have been reported from several other isotopic studies in humid regions (e.g. Sklash and Farvolden, 1979; Kennedy et al., 1986; Uhlenbrook et al., 2008) demonstrating that pre-event water and subsurface water contributions during episodes is a dominant process. Also the results fall well into the range of what was reported by others for catchments with similar climatic conditions (Hrachowitz et al., 2011; Munyaneza et al., 2012). Although generally in line with these previous studies, few have previously addressed the role of catchment wetting-up for runoff generation. While, groundwater sustained the flow during dry periods, more rapid runoff generation processes with larger event water fractions was observed as the catchment became successively wetter.

Runoff generation processes during the wet-up phase in asemi-arid basin

H. Zarei et al.

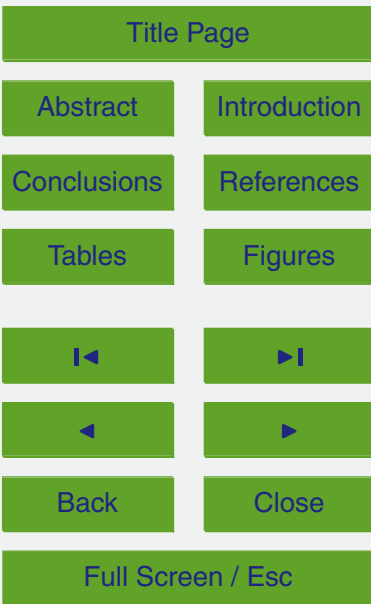

Printer-friendly Version

Interactive Discussion 


\section{Conclusions}

This study focused on the use of hydrometric measurements in combination with natural isotopic tracer methods for identifying the dominant runoff generation processes in a semi-arid karst basin. The results illustrate that runoff ratio generally is low indicating 5 that only a small proportion of rainfall is translated into stream water during events, especially during the first phase of the wet season. Higher runoff ratios and larger event water fractions following catchment wet-up, were shown to be directly linked to changes in soil moisture, which in turn controlled the runoff generation processes. Over all, the results suggest that the storm event hydrology are sensitive the amount of catchment wet-up and hence could be strongly impacted if the timing, duration and amount of precipitation change in the future.

Acknowledgements. This work was partly funded by the Ministry of Science, Research and Technology (MSRT) of Iran to Heidar Zarei visiting scholarship to SLU in Sweden. Authors would like to thank lan Clark director of the G. G. Hatch Stable Isotope Laboratory of Ottawa

\section{References}

Abbaspour, K. C., Faramarzi, M., Ghasemi, S. S., and Yang, H.: Assessing the impact of climate change on water resources in Iran, Water Resour. Res., 45, W10434, doi:10.1029/2008WR007615, 2009.

Alijani, B. and Harman, J. R.: Synoptic climatology of precipitation Iran, Ann. Assoc. Am. Geogr., 75, 404-416, 1985.

Anonymous: Geological Report, Abolabas Dam studies, Khuzestan Water and Power Authority, 159 pp., 2007.

Aquilina, L., Ladouche, B., and Dörfliger, N.: Water storage and transfer in the epikarst of karstic

HESSD

11, 3787-3810, 2014

Runoff generation

processes during the

wet-up phase in

asemi-arid basin

H. Zarei et al.

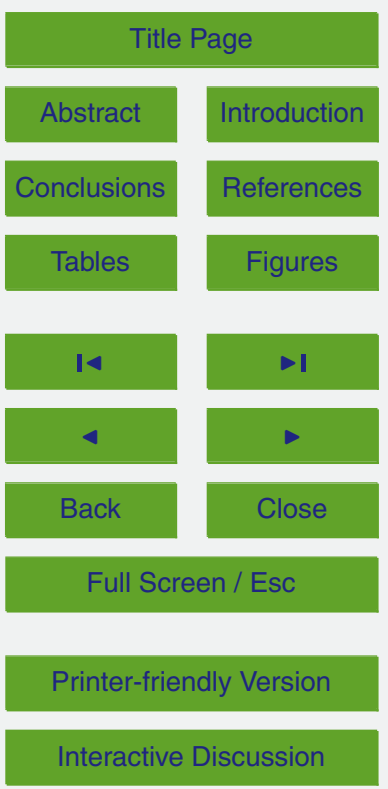


Ballato, P., Mulch, A., Landgraf, A., Strecker, M. R., Dalconi, M. C., Friedrich, A., and Tabatabaei, S. H.: Middle to late Miocene Middle Eastern climate from stable oxygen and carbon isotope data, southern Alborz mountains, N Iran, Earth Planet. Sc. Lett., 300, 125138, 2010.

5 Blume, T., Zehe, E., and Bronstert, A.: Investigation of runoff generation in a pristine, poorly gauged catchment in the Chilean Andes II: Qualitative and quantitative use of tracers at three spatial scales, Hydrol. Process., 22, 3676-3688, 2008.

Buttle, J. M.: Isotope hydrograph separations and rapid delivery of pre-event water from drainage basins, Prog. Phys. Geogr., 18, 16-41, 1994.

10 Chen, L., Zheng, H., David Chen, Y., and Liu, C.: Base-flow separation in the source region of the Yellow River, J. Hydrol. Eng., 13, 541-548, 2008.

De Groot, P. A.: Handbook of Stable Isotope Analytical Techniques, Elsevier, Amsterdam, 2008.

Didszun, J. and Uhlenbrook, S.: Scaling of dominant runoff generation processes: INested catchments approach using multiple tracers, Water Resour. Res., 44, W02410, doi:10.1029/2006WR005242, 2008.

Hemadi, K., Jamei, M., and Houseini, F. Z.: Climate change and its effect on agriculture water requirement in Khuzestan plain, Iran, J. Food Agric. Environ., 9, 624-628, 2011.

Hooper, R. P. and Shoemaker, C. A.: A comparison of chemical and isotopic hydrograph separation, Water Resour. Res., 22, 1444-1454, 1986.

20 Hrachowitz, M., Bohte, R., Mul, M. L., Bogaard, T. A., Savenije, H. H. G., and Uhlenbrook, S.: On the value of combined event runoff and tracer analysis to improve understanding of catchment functioning in a data-scarce semi-arid area, Hydrol. Earth Syst. Sci., 15, 2007-2024, doi:10.5194/hess-15-2007-2011, 2011.

Jones, I. C., Banner, J. L., and Humphrey, J. D.: Estimating recharge in a tropical Karst Aquifer, Water Resour. Res., 36, 1289-1299, 2000.

Katz, B. G., Coplen, T. B., Bullen, T. D., and Davis, J. H.: Use of chemical and isotopic tracers to characterize the interactions between ground water and surface water in mantled Karst, Ground Water, 35, 1014-1028, 1997.

Kennedy, V. C., Kendall, C., Zellweger, G. W., Wyerman, T. A., and Avanzino, R. J.: Determination of the components of stormflow using water chemistry and environmental isotopes, Mattole River basin, California, J. Hydrol., 84, 107-140, 1986.

Laudon, H. and Slaymaker, O.: Hydrograph separation using stable isotopes, silica and electrical conductivity: an alpine example, J. Hydrol., 201, 82-101, 1997.

\section{HESSD}

$11,3787-3810,2014$

Runoff generation

processes during the wet-up phase in asemi-arid basin

H. Zarei et al.

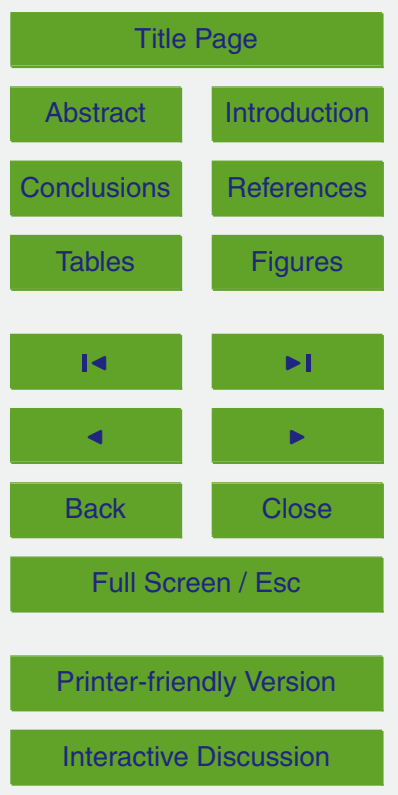


Laudon, H., Sjöblom, V., Buffam, I., Seibert, J., and Mörth, M.: The role of catchment scale and landscape characteristics for runoff generation of boreal streams, J. Hydrol., 344, 198-209, 2007.

Lyon, S. W., Desilets, S. L. E., and Troch, P. A.: Characterizing the response of a catchment 5 to an extreme rainfall event using hydrometric and isotopic data, Water Resour. Res., 44, W06413, doi:10.1029/2007WR006259, 2008.

Mcdonnell, J. J., Bonell, M., Stewart, M. K., and Pearce, A. J.: Deuterium variations in storm rainfall - implications for stream hydrograph separation, Water Resour. Res., 26, 455-458, 1990.

10 Mul, M. L., Mutiibwa, R. K., Uhlenbrook, S., and Savenije, H. H. G.: Hydrograph separation using hydrochemical tracers in the Makanya catchment, Tanzania, Phys. Chem. Earth, 33, 151-156, 2008.

Munyaneza, O., Wenninger, J., and Uhlenbrook, S.: Identification of runoff generation processes using hydrometric and tracer methods in a meso-scale catchment in Rwanda, Hydrol. Earth Syst. Sci., 16, 1991-2004, doi:10.5194/hess-16-1991-2012, 2012.

Pinder, G. F. and Jones, J. F.: Determination of the ground-water component of peak discharge from the chemistry of total runoff, Water Resour. Res., 5, 438-445, 1969.

Rallison, R. E. and Miller, N.: Past, Present and Future SCS Runoff Procedure, Proceedings of the International Symposium on Rainfall-Runoff Modeling, Mississippi State University, 20 Mississippi State, 1981.

Rezaei Sadr, H., Akhoond Ali. A. M., Radmanesh, F., and Parham, G. A.: Nonlinearity in storage-discharge relationship and its influence on flood hydrograph prediction in mountainous catchments, Int. J. Water Resour. Env. Eng., 4, 208-217, 2012.

Richey, G. D., McDonnell, J. J., Erbe, W. M., and Hurd, M. T.: Hydrograph separation based on chemical and isotopic concentrations: a critical appraisal of published studies from New Zealand, North America and Europe, J. Hydrol., 37, 95-111, 1998.

Roshan, G. R. and Grab, S. W.: Regional climate change scenarios and their impacts on water requirements for wheat production in Iran, Int. J. Plant. Prod., 6, 239-265, 2012.

Saghafian, B. and Ghermez Cheshmeh, B.: Spatial variation of flood severity index, Iran-Water Resour. Res., 4, 28-39, 2008.

Singh, V. P.: Hydrologic Systems: Rainfall-runoff Modeling, Prentice Hall, Englewood Cliffs, New Jersey, 1988.
HESSD

11, 3787-3810, 2014

Runoff generation

processes during the wet-up phase in asemi-arid basin

H. Zarei et al.

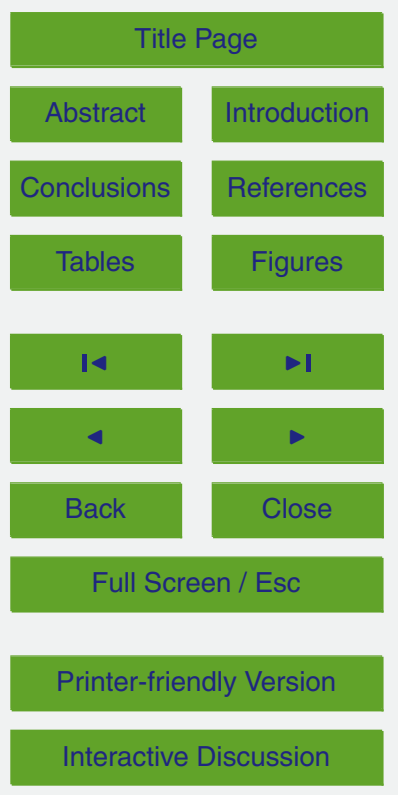


Sklash, M. G. and Farvolden, R. N.: The role of groundwater in storm runoff, J. Hydrol., 43, 45-65, 1979.

Uhlenbrook, S., Frey, M., Leibundgut, C., and Maloszewski, P.: Hydrograph separations in a mesoscale mountainous basin at event and seasonal timescales, Water Resour. Res., 38, 1096-1110, doi:10.1029/2001WR000938, 2002.

Uhlenbrook, S., Didszun, J., and Wenninger, J.: Source areas and mixing of runoff components at the hillslope scale - a multi-technical approach, Hydrolog. Sci. J., 53, 741-753, 2008.

Wels, C., Cornett, R. J., and Lazerte, B. D.: Hydrograph separation: a comparison of geochemical and isotopic tracers, J. Hydrol., 122, 253-274, 1991.

10 Wenninger, J., Uhlenbrook, S., Lorentz, S., and Leibundgut, C.: Identification of runoff generation processes using combined hydrometric, tracer and geophysical methods in a headwater catchment in South Africa, Hydrolog. Sci. J., 53, 500-500, 2008.

Zohrabi, N., Bavani, A. R. M., Sedghi, H., and RasolTelvari, A.: Analyzing the two-dimensional plot of the interannual climate variability for detection of the climate change in the Large

Karoun River Basin, Iran, Afr. J. Biotechnol., 10, 4138-4146, 2011.

\section{HESSD}

$11,3787-3810,2014$

Runoff generation

processes during the

wet-up phase in

asemi-arid basin

H. Zarei et al.

Title Page

Abstract

Introduction

Conclusions

Tables

References

Figures

14

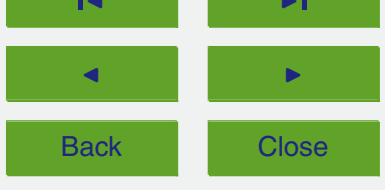

Full Screen / Esc

Printer-friendly Version

Interactive Discussion 


\section{HESSD}

11, 3787-3810, 2014

Table 1. Characteristics of the rainfall-runoff events $\left(P\right.$, amount of precipitation; $I_{\mathrm{p}}$, intensity of precipitation; $Q_{0}$, initial stream flow; $Q_{\max }$, peak flow; RR, Runoff Ratio of event).

\begin{tabular}{lllllllrr}
\hline Event & Date & $\begin{array}{l}\text { Antecedent } \\
\text { moistures } \\
\mathrm{mm}\end{array}$ & $P$ & $\begin{array}{l}\text { Cumulative } \\
\text { rainfall }\end{array}$ & $I_{\mathrm{p}}$ & $Q_{0}$ & $Q_{\max }$ & $\mathrm{RR}$ \\
& & $\mathrm{mm}$ & $\mathrm{mm} \mathrm{h}^{-1}$ & $\mathrm{~m}^{3} \mathrm{~s}^{-1}$ & $\mathrm{~m}^{3} \mathrm{~s}^{-1}$ & $(\%)$ \\
\hline $1^{*}$ & 13 Dec 2010 & 1.0 & 12.0 & 15.3 & 21.35 & 0.36 & 2.23 & 0.8 \\
$2^{*}$ & 15 Jan 2011 & 31.0 & 25.2 & 88.7 & 9.63 & 0.81 & 7.41 & 2.6 \\
3 & 27 Jan 2011 & 2.5 & 29.5 & 131.3 & 9.60 & 1.11 & 4.12 & 2.9 \\
$4^{*}$ & 31 Jan 2011 & 35.0 & 21.0 & 155.6 & 10.87 & 1.50 & 11.90 & 4.2 \\
5 & 8 Feb 2011 & 9.0 & 19.0 & 190.0 & 6.0 & 1.50 & 3.31 & 5.3 \\
6 & 10 Feb 2011 & 28.0 & 14.5 & 214.0 & 6.0 & 1.64 & 6.64 & 8.3 \\
7 & 11 Feb 2011 & 25.0 & 15.5 & 242.0 & 8.1 & 2.00 & 11.20 & 10.5 \\
\hline
\end{tabular}

${ }^{*}$ The three isotopic sampled events.

Antecedent Moistures was calculated based on the accumulative rainfall in the 5 days ago.

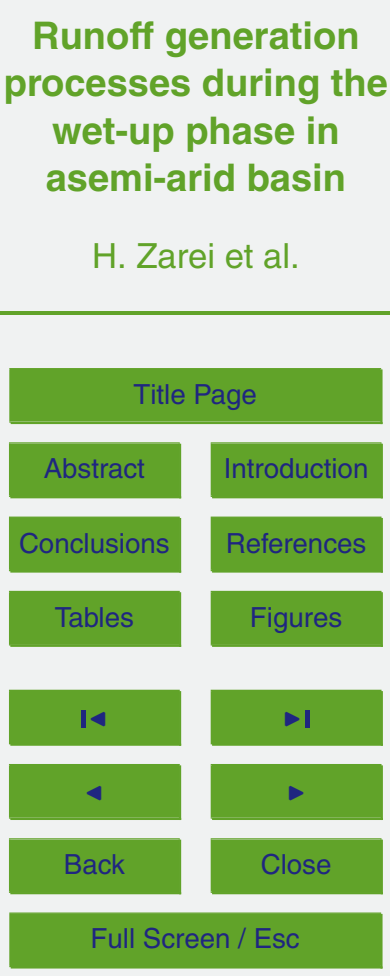

Printer-friendly Version

Interactive Discussion 
Table 2. Strength of regression (adjusted $R$ ) between Runoff Ratio and Characteristics of the rainfall-runoff events.

\begin{tabular}{lllllll}
\hline & $\begin{array}{l}\text { Antecedent } \\
\text { Moistures }\end{array}$ & $\begin{array}{l}\text { Cumulative } \\
\text { Rainfall }\end{array}$ & $Q_{0}$ & $Q_{\max }$ & $I_{\mathrm{p}}$ & $P$ \\
\hline Regression type & $\begin{array}{l}\text { Ascending } \\
\text { Power }\end{array}$ & Exponential & Exponential & Power & Exponential & Linear \\
$R$ & 0.74 & 0.99 & 0.97 & 0.66 & 0.88 & 0.34 \\
$P$ value & 0.05 & 0.001 & 0.001 & 0.1 & 0.01 & 0.1 \\
\hline
\end{tabular}

Runoff generation processes during the wet-up phase in asemi-arid basin

H. Zarei et al.

Title Page

Abstract Introduction

Conclusions References

Tables Figures

14

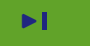

4

Back

Close

Full Screen / Esc

Printer-friendly Version

Interactive Discussion 
Table 3. Isotopic contents observed in the study catchment during the investigated events.

\begin{tabular}{|c|c|c|c|c|c|c|c|}
\hline & \multirow[b]{2}{*}{ Parameter } & \multicolumn{2}{|c|}{ Event 1} & \multicolumn{2}{|c|}{ Event 2} & \multicolumn{2}{|l|}{ Event 4} \\
\hline & & $\begin{array}{l}\delta^{18} \mathrm{O} \\
(\% \circ \mathrm{VSI}\end{array}$ & $\begin{array}{c}\delta^{2} \mathrm{H} \\
\mathrm{OW})\end{array}$ & $\delta^{18} \mathrm{O}$ & $\delta^{2} \mathrm{H}$ & $\delta^{18} \mathrm{O}$ & $\delta^{2} \mathrm{H}$ \\
\hline pre-event water & Mean & -4.77 & -21.19 & -4.85 & -24.00 & -4.83 & -25.20 \\
\hline River & $\begin{array}{l}\text { Count } \\
\text { Max } \\
\text { Mean } \\
\text { Min } \\
\text { Std }\end{array}$ & $\begin{array}{l}10 \\
-4.51 \\
-4.65 \\
-4.77 \\
0.07\end{array}$ & $\begin{array}{l}10 \\
-20.98 \\
-21.89 \\
-23.06 \\
0.68\end{array}$ & $\begin{array}{l}16 \\
-2.91 \\
-3.95 \\
-4.85 \\
0.71\end{array}$ & $\begin{array}{l}16 \\
-5.09 \\
-15.72 \\
-24.00 \\
6.63\end{array}$ & $\begin{array}{l}16 \\
-4.3 \\
-4.73 \\
-4.91 \\
0.17\end{array}$ & $\begin{array}{l}16 \\
-20.12 \\
-24.39 \\
-27.14 \\
2.02\end{array}$ \\
\hline Rain & $\begin{array}{l}\text { Count } \\
\text { Max } \\
\text { Mean } \\
\text { Min } \\
\text { Std }\end{array}$ & $\begin{array}{l}6 \\
-0.90 \\
-1.95 \\
-2.83 \\
0.76\end{array}$ & $\begin{array}{l}6 \\
-2.20 \\
-7.74 \\
-13.72 \\
4.33\end{array}$ & $\begin{array}{l}6 \\
-0.13 \\
-1.50 \\
-2.06 \\
0.71\end{array}$ & $\begin{array}{l}6 \\
15.25 \\
7.34 \\
3.92 \\
4.14\end{array}$ & $\begin{array}{l}6 \\
-3.07 \\
-3.73 \\
-4.21 \\
0.43\end{array}$ & $\begin{array}{l}6 \\
-12.50 \\
-17.55 \\
-21.36 \\
3.36\end{array}$ \\
\hline
\end{tabular}

Std: Standard deviation.

HESSD

$11,3787-3810,2014$

Runoff generation processes during the wet-up phase in asemi-arid basin

H. Zarei et al.

Title Page

Abstract

Introduction

Conclusions

References

Tables

Figures

14

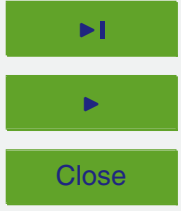

Back

Full Screen / Esc

Printer-friendly Version

Interactive Discussion 


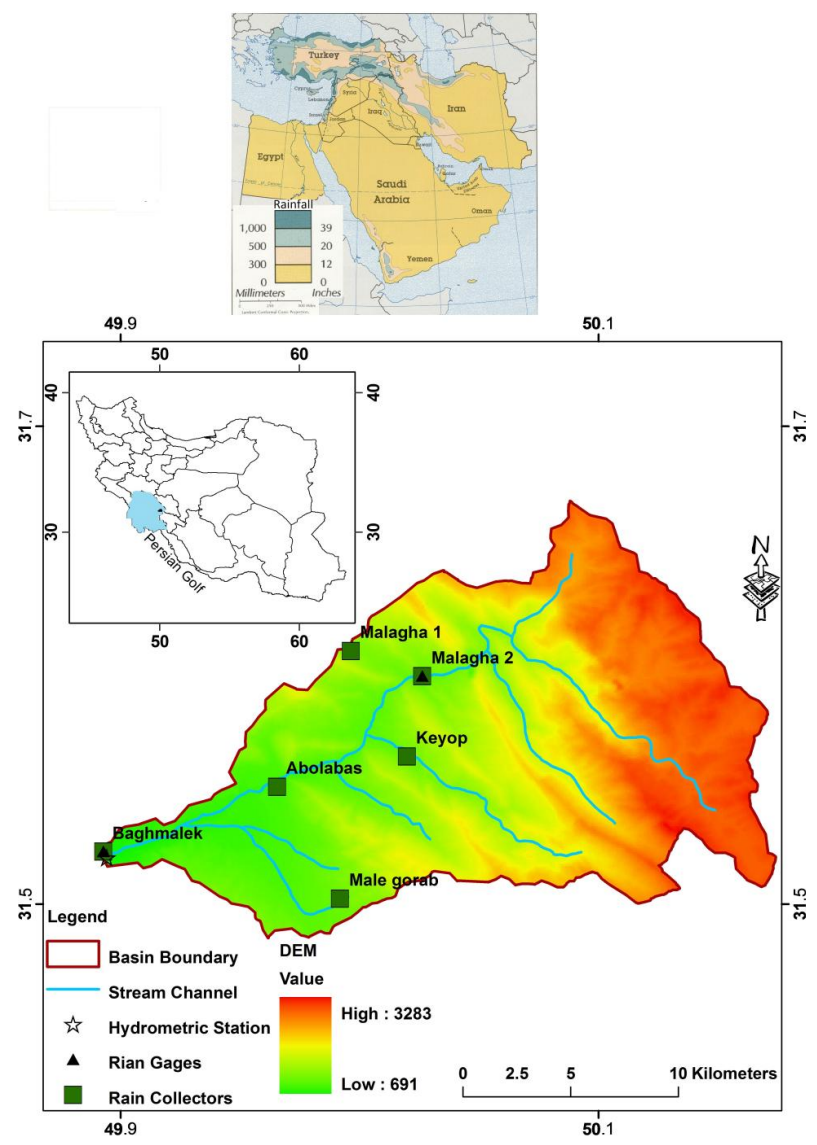

\section{HESSD}

11, 3787-3810, 2014

Runoff generation processes during the wet-up phase in asemi-arid basin

H. Zarei et al.

Title Page

Abstract Introduction

Conclusions

References

Tables

Figures

14

Back

Full Screen / Esc

Printer-friendly Version

Interactive Discussion 


\section{HESSD}

11, 3787-3810, 2014

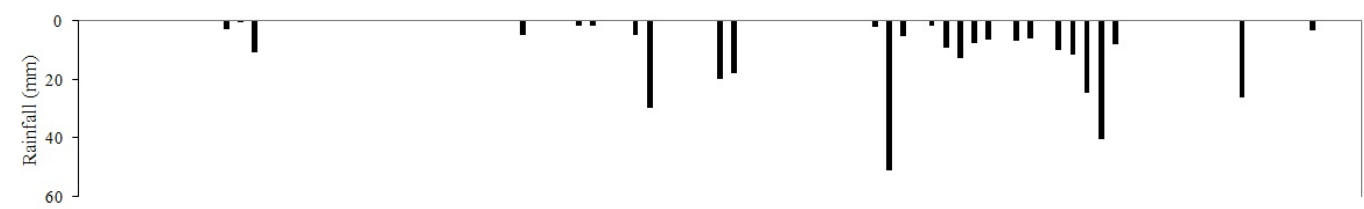

Runoff generation processes during the wet-up phase in asemi-arid basin

H. Zarei et al.

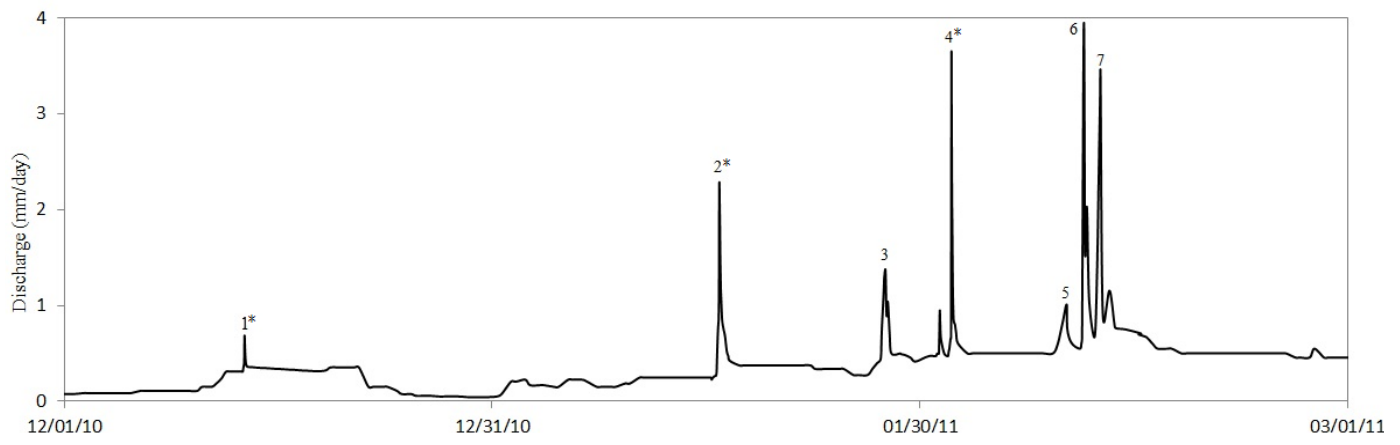

Fig. 2. Time series of rainfall and runoff for during wet season of hydrologic year 2010-2011 (October to April) at Pole Manjeniq station. The numbering of the event (1-7) are the labels for the events used throughout. The events marked with asterisks $\left({ }^{*}\right)$ are the events analyzed for $\left(\delta^{18} \mathrm{O}\right)$ and deuterium $\left(\delta^{2} \mathrm{H}\right)$.

Title Page

Abstract Introduction

Conclusions

References

Tables

Figures

14

$>1$

4

Back

Close

Full Screen / Esc

Printer-friendly Version

Interactive Discussion 

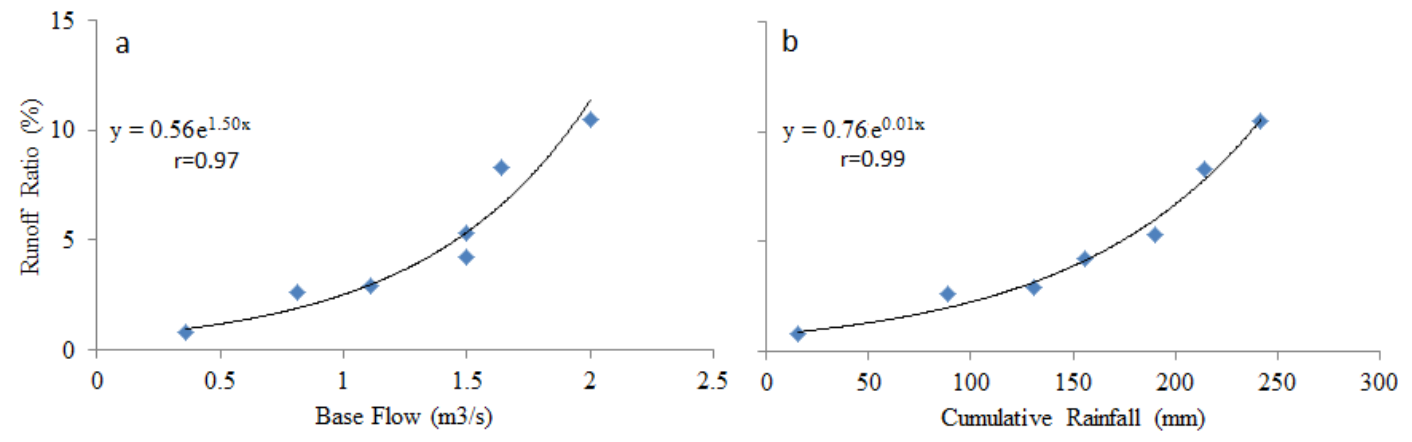

\section{HESSD}

$11,3787-3810,2014$

Runoff generation processes during the wet-up phase in asemi-arid basin

H. Zarei et al.

\section{Title Page}

Abstract Introduction

Conclusions References

Tables Figures

Fig. 3. The correlation between runoff ratio (a) base flow and (b) cumulative rainfall.

14

4

Back

Full Screen / Esc

Printer-friendly Version

Interactive Discussion 

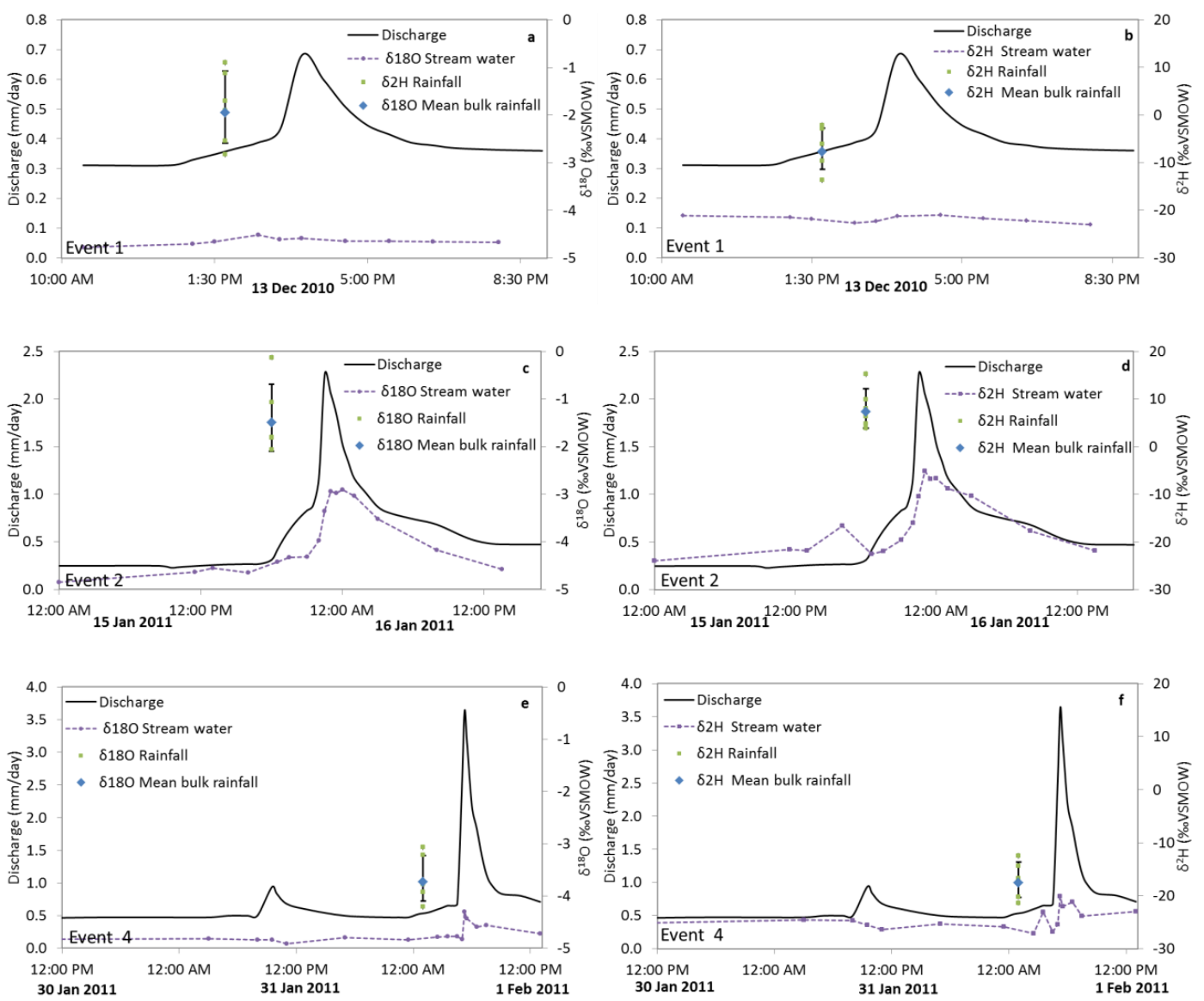

Fig. 4. Variations of $\delta^{18} \mathrm{O}$ and $\delta^{2} \mathrm{H}$ during three investigated events. The error bars in the rainfall denotes the standard deviation of the precipitation.

\section{HESSD}

11, 3787-3810, 2014

Runoff generation processes during the wet-up phase in asemi-arid basin

H. Zarei et al.

\section{Title Page}

\section{Abstract}

Introduction

Conclusions

References

Tables

Figures

14

$>1$

4

Back

Close

\section{Full Screen / Esc}

Printer-friendly Version

Interactive Discussion 

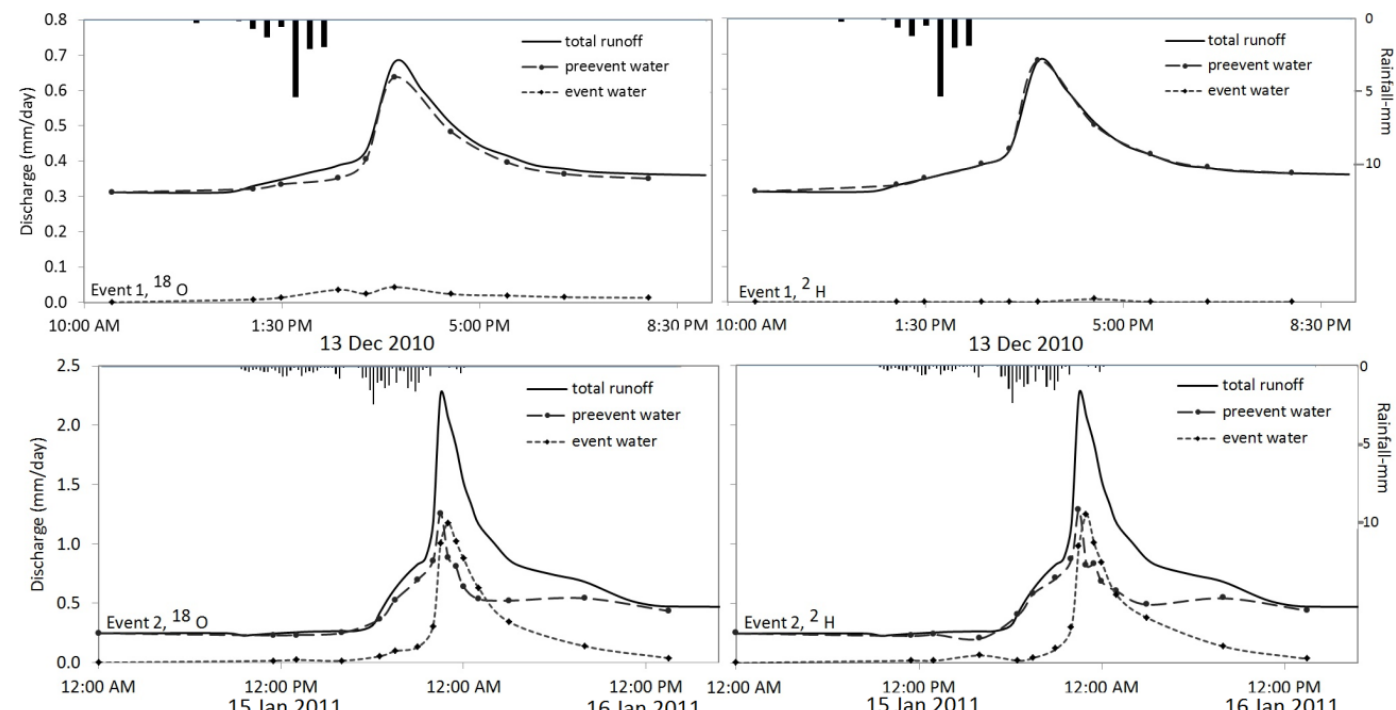

HESSD

11, 3787-3810, 2014

Runoff generation processes during the wet-up phase in asemi-arid basin

H. Zarei et al.

\section{Title Page}

Abstract

Introduction
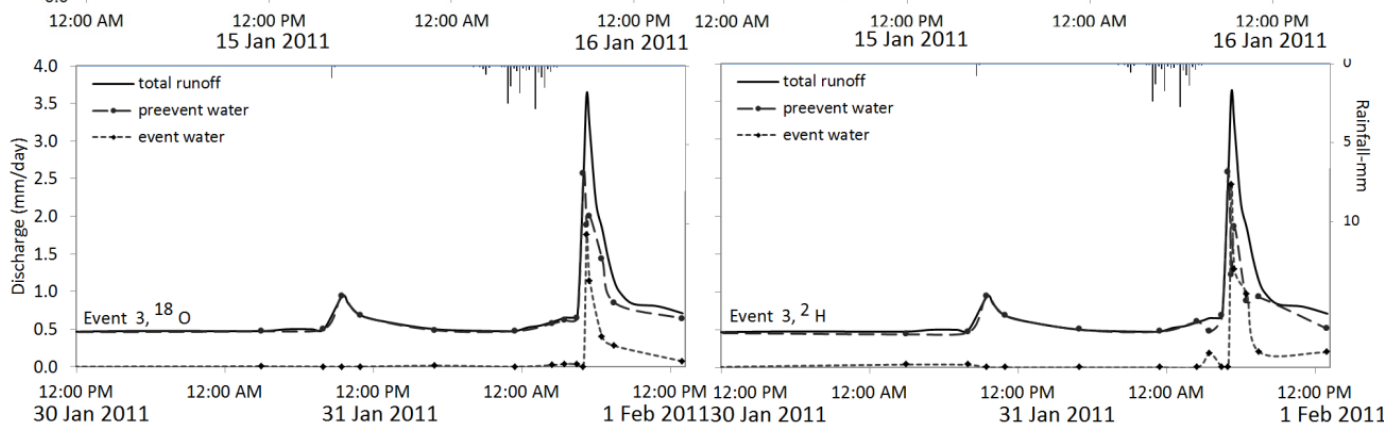

Conclusions

References

Tables

Figures

14

।

4

Back

Close

\section{Full Screen / Esc}

Printer-friendly Version

Fig. 5. Two-component hydrograph separations for three events using ${ }^{18} \mathrm{O}$ (a) and ${ }^{2} \mathrm{H}$ (b) at Pole Manjeniq station. 